\title{
Kajian Terhadap Variasi Metode dan Bahan Pengawet pada Proses Pengawetan Bambu-Kayu di Indonesia
}

\author{
Efa Suriani \\ Universitas Islam Negeri Sunan Ampel Surabaya, Jawa Timur, Indonesia \\ efasuriani@gmail.com \\ doi.org/ 10.29080/emara.v4i1.338
}

\begin{abstract}
Bamboo and wood are natural materials, each of which has a variety of uniqueness. Among its uniqueness is an irreplaceable building material between one another. However, weaknesses are also found in them especially related to termites or powder beetles. To be able to obtain maximum results in the use of these two materials, the preservation process was needed as a special treatment. With a variety of Bamboo preservation techniques, this paper tries to identify and examine various studies and best practices related to the Bambu-kayu preservation method in Indonesia. A qualitative approach was used with literature study techniques, field observations and in-depth interviews with entrepreneurs in preserving bamboo. From the results of the study obtained an illustration that the preservation method carried out depends on the needs of the user. It is also known that $10 \%$ Borak Boric concentrate has been able to be a chemical preservative that can be trusted to maximize material age. There should also be research on other preservatives, both chemical ones such as pyrolysis oil from plastic waste, as well as natural ones such as coconut shell liquid smoke and tobacco. Further research can also be focused on the strength of bamboo preserved by the preservation / boiling method. In addition to optimal material service age, it is necessary to consider several other criteria such as the ability to be mass produced / according to industry needs and able to be implemented significantly. Thus, it is expected that preservatives will be obtained that are safe for humans, environmentally friendly, workable and economical.
\end{abstract}

Keywords: preservation method, preservation material, bamboo-wood

\begin{abstract}
Abstrak: Bambu dan kayu merupakan bahan alami yang memiliki berbagai keunikannya masing-masing. Diantara keunikannya adalah bahan bangunan yang tidak tergantikan antara satu dengan yang lainnya. Namun, kelemahan juga ditemukan pada material bambu dan kayu terutama terkait rayap atau kumbang bubuk. Untuk dapat memperoleh hasil yang maksimal dalam penggunaan ke dua material tersebut maka diperlukan proses pengawetan sebagai perlakuan khusus. Dengan berbagai macam teknik pengawetan Bambu-Kayu, maka tulisan ini mencoba mengidentifikasi dan mengkaji berbagai penelitian serta best practice terkait metode pengawetan Bambu-kayu di Indonesia. Pendekatan kualitatif digunakan dengan teknik studi literatur, pengamatan lapangan serta wawancara mendalam kepada para pengusaha pengawetan bambu-kayu. Dari hasil kajian diperoleh gambaran bahwa metode pengawetan yang dilakukan tergantung dengan kebutuhan pengguna. Selain itu diketahui bahwa Borak Boric konsetrasi 10\% telah mampu menjadi bahan pengawet kimia yang dapat dipercaya mampu memaksimalkan usia material dengan baik. Perlu juga dilakukan penelitian terhadap bahan pengawet lainnya, baik yang bersifat kimiawi seperti minyak pirolisis dari sampah plastik, maupun yang bersifat alami seperti asap cair tempurung kelapa dan tembakau. Penelitian lanjutan juga dapat difokuskan kekuatan kayubambu yang diawetkan dengan metode pengawetan/perebusan. Selain usia pemakaian material yang optimal, perlu dipertimbangkan beberapa kriteria lain seperti kemampuan untuk diproduksi secara massal / sesuai kebutuhan industri serta mampu diterapkan secara signifikan. Dengan demikian diharapkan akan diperoleh bahan pengawet yang aman bagi manusia, ramah lingkungan, workable dan ekonomis.
\end{abstract}

Kata Kunci: metode pengawetan, bahan pengawetan, bambu-kayu 


\section{PENDAHULUAN}

Permintaan bahan baku material untuk konstruksi bangunan semakin meningkat. Saat ini penggunaan bambu sebagai bahan konstruksi sudah mulai dilirik oleh masyarakat. Dalam dunia desain perancangan, arsitektur konstruksi bambu yang khas/artistik dan alami menjadi daya tarik tersendiri sehingga memiliki penggemar yang ingin mendirikan bangunan dari material bambu. Bambu merupakan salah satu alternatif material ekologis atau green material yang penerapannya merupakan pemenuhan pada aspek green building dan salah satu cara dalam menjaga ekosistem bumi atau pencegahan dari pemanasan global (Suriani, 2017).

Bambu sebagai bahan alami memiliki kelemahan pada ketahanan terhadap rayap maupun kumbang bubuk. Untuk itu pemakaian bambu sebagai bahan bangunan atau lainnya, jika diharapkan memiliki service layan atau usia pemakaian yang lama dan maksimal maka, perlu treatment pendahuluan yaitu pengawetan terlebih dahulu. Bahan pengawet yang baik adalah dapat digunakan untuk kepentingan komersial pada umumnya, harus beracun terhadap perusak kayu, permanen, lebih mudah meresap, aman jika dipakai, tidak merusak kayu dan logam, banyak tersedia dan murah (Hirmawan, Kurniawati, \& Indriyani, 2010), Hal serupa juga dapat diperkirakan jika menggunakan kayu sebagai bahan bangunan. Kayu merupakan bahan yang berasal dari alam. Sehingga, kayu perlu diawetkan terlebih dahulu bila diinginkan usia layan yang baik. Kayu dan bambu memiliki kelebihan dan ciri khas masing-masing dan tidak bisa digantikan antara satu sama lain.

Terdapat 2 jenis metode pengawetan (Sulistyowati, 1997), yaitu metode non-kimia (tradisional) dan metode kimia. Metode non-kimia sudah lama digunakan oleh para leluhur di masyarakat. Menggunakan pengawetan metode kimia memerlukan biaya yang dikeluarkan untuk membeli bahan pengawet. Akan tetapi, menghasilkan perlindungan yang lebih baik. Kesuksesan metode ini sangat tergantung pada konsenterasi larutan pengawet yang diberikan pada bahan bambu atau kayu. Kategori metode pengawetan dikatakan ekonomis jika usia layan bambu dapat bertahan sampai dengan 10 sampai dengan 15 tahun, pada posisi bambu diluar ruangan. Pada usia layan 15 sampai dengan 25 tahun jika bambu ditempatkan di dalam ruangan tertutup.

Mengetahui metode dan bahan yang dapat digunakan sebagai alternatif untuk pengawetan dan jumlah konsenterasi yang dilarutkan adalah suatu informasi yang penting untuk tercapainya usia layan maksimal yang diinginkan. Sehingga, studi tentang metode dan bahan pengawet pada pengawetan bambu-kayu perlu dilakukan khususnya penelitian pengawetan yang ada di Indonesia.
Tujuan artikel ini untuk memperoleh gambaran atau informasi tentang metode, bahan pengawet apa saja yang dapat digunakan, berapa persentase konsenterasi yang dilarutkan, dan selanjutnya dibandingkan dengan pengawetan yang dilakukan real di lapangan/masyarakat. Serta, temuan lain dari penelitian. Informasi ini dapat menjadi rujukan, apa saja yang dapat dilakukan selanjutnya untuk pengembangan pengawetan bambu dan kayu. Sehingga, memperoleh bahan pengawet yang aman bagi manusia, ramah lingkungan, workable atau mudah dilakukan dan ekonomis sehingga dapat diterapkan di masyarakat.

\subsection{Pengawetan Bambu}

Metode pengawetan bambu masih terkadang mengacu pada pengawetan kayu. Sedangkan, standar yang ada baru berupa pedoman. Pedoman tersebut yang berjudul tata cara pengawetan bambu bulat dengan cara tekanan. Pedoman tersebut dapat dilihat pada pedoman kode Pd-T-07-2004-C. Seperti yang telah diketahui sebelumnya bambu sebagai bahan alami harus diawetkan agar dapat bertahan lama dan terhindar dari serangan bubuk (serangga/hama). Agar dapat mencapai tujuan tersebut getah yang terdapat dalam bambu harus dikeluarkan terlebih dahulu, sehingga bambu dapat lebih awet, mempunyai daya lenting tinggi, tidak mudah patah dan mudah diolah atau dianyam jika digunakan untuk interior/bahan kerajinan (Charomaini $Z, 2014)$. Selain itu, bambu agar tidak mudah lapuk harus dilapisi dengan cat, kapur, atau vernis.

Menurut (Charomaini Z, 2014), pengawetan yang dilakukan pada bambu dapat dilakukan dengan beberapa cara, yaitu:

a. Getah atau zat pati yang ada pada bambu dikeluarkan dan diganti dengan bahan yang tidak disukai oleh serangga. Metode yang sederhana yaitu, dengan jalan merendam bambu dalam air berlumpur, mengalir, lebih kurang 2 bulan. Kemudian dikeringkan di tempat teduh dan terhindar dari panas matahari.

b. Merendam bambu dalam larutan konsenterasi $5 \%$ asam boraks dilarutkan dalam air.

c. Menggunakan garam sebagai pengganti gula yang ada pada batang bambu.

d. Menggunakan minyak tanah atau oli bekas dengan cara melumurkannya pada batang.

e. Perendaman dan pemanasan.

Beberapa metode pengawetan bambu yang dapat dipakai (Sulistyowati, 1997) adalah:

a. Curing; metode ini bertujuan mengurangi kandungan pati dalam bambu dengan memanfaatkan proses asimilasi pada daun yang masih berlangsung. Namun, metode ini tidak berpengaruh pada serangan jamur atau rayap. 
b. Pengasapan; bambu ditempatkan daiatas tungku selama waktu tertentu sampai pengaruh asap menghitamkan batang bambu. Sehingga, pemanasan pada bambu dapat mengakibatkan terurainya senyawa pati dalam parenkim.

c. Pelaburan; batang bambu dilaburi dengan tohor $(\mathrm{Ca}(\mathrm{OH}) 2)$ untuk menghambat penyerapan air. Namun, perlu pembuktian terhadap pengaruh senyawa alkali terhadap kekuatan bambu.

d. Perendaman dalam air; bambu direndam dalam air sebaiknya tidak lebih dari 1 bulan.

e. Perebusan; bambu direbus pada suhu 100 derajat Celcius selama 1 jam cukup efektif mengurangi serangan kumbang bubuk.

f. Metode Butt treatment; metode ini baik dilakukan pada bambu pendek dan kadar air tinggi, karena memakan waktu yang lama. Bagian bawah bambu dipotong dan diletakkan dalam tangki berisi pengawet. Cabang dan daun batang tetap disisakan. Melalui proses transpirasi daun bahan pengawet dialirkan pada batang.

g. Metode Tangki Terbuka; batang bambu dengan ukuran tertentu direndam beberapa hari dalam campuran bahan pengawet

h. Metode Boucherie; batang bambu dipotong sesuai ukuran tertentu, kemudian bambu dimasukkan ke dalam mesin Boucherie. Dengan bagian khusus pada mesin, cairan pengawet konsenterasi tertentu dialirkan dengan tekanan $0,8-1,5 \mathrm{~kg} / \mathrm{m} 2$ pada batang bambu.

i. Metode Kimia Sederhana; bambu segar didirikan terbalik. Ujung bagian atas dimasukkan tabung yang berisi solar. Dengan memanfaatkan gaya gravitasi, minyak solar mendesak keluar cairan yang memakan waktu seminggu.

Cara sederhana untuk mengawetkan bambu segar yang baru ditebang dapat menggunakan senyawa boron (Barly \& Sumarni, 1997). Benda uji yang dipakai adalah 18 batang bambu dengan panjang dan diameter bervariasi yang diperoleh dari Ciapus, Bogor. Batang bambu tersebut direndam masing-masing selama satu, tiga dan lima hari. Hasil penelitian menunjukkan retensi dipengaruhi oleh waktu pengawetan dan konsentrasi larutan yang digunakan. Hubungan keduanya menunjukkan perbedaan yang nyata. Retensi maksimum sebesar $7,64 \mathrm{~kg} / \mathrm{m} 3$ yaitu, batang bambu direndam selama lima hari dengan konsenterasi senyawa boron sebanyak $10 \%$.

\subsection{Pengawetan Kayu}

Standarisasi pengawetan kayu tercantum pada Standar Nasional Indonesia atau SNI, nomor 035010.1-1999 yang berjudul pengawetan kayu untuk perumahan dan gedung. Dalam (SNI 03-5010.1-1999, n.d.), disebutkan bahwa pengawetan kayu merupakan suatu proses memasukkan bahan pengawet ke dalam kayu terhadap serangan organisme perusak kayu sehingga dapat memperpanjang masa pakai kayu. Sedangkan, bahan pengawet adalah suatu bahan kimia yang bila dimasukkan ke dalam kayu dapat meningkatkan ketahanan kayu dan serangan organisme perusak kayu yaitu, serangga (rayap tanah, rayap kayu kering, bubuk kayu kering) dan jamur perusak kayu. Pengawetan yang dapat dilakukan meliputi pengawetan secara vakum-tekan, pengawetan secara rendaman dingin, dan pengawetan secara rendaman panas dan dingin.

Pengawetan kayu mangium (Acacia mangium Willd) dengan metode rendaman panas dan dingin hanya dapat dilakukan untuk pemakaian dibawah atap tanpa berhubungan langsung dengan tanah (Djarwanto \& R.Sudradjat, 2002). Bahan pengawet yang digunakan adalah golongan boron dan golongan CCB dengan konsenterasi larutan sebanyak $10 \%$. Lama rendaman panas dilakukan masing-masing selama satu jam dan tiga jam.

\section{METODE PENELITIAN}

Penelitian ini bertujuan untuk memperoleh gambaran metode dan bahan pengawet untuk pengawetan bambu-kayu yang telah diteliti khususnya berlokasi di Indonesia. Kemudian, dibandingkan dengan survei lapangan yang digunakan oleh masyarakat dalam hal ini diwakili dalam proses pengawetan bambu. Pendekatan penelitian menggunakan pendekatan kualitatif, metode observasi lapangan dan wawancara pada pengusaha/perajin bambu awet oleh peneliti. Teknik pengumpulan data melalui studi literatur dan hasil observasi lapangan. Data dianalisis secara deskriptif Lokasi survei untuk melakukan observasi pelaksanaan pengawetan bambu dipilih di Kota Yogyakarta, yaitu pada perusahaan CV.Rumpun Bambu Nusantara. Sedangkan, studi literatur digunakan dengan menelaah 39 publikasi pada kuruan waktu 15 tahun terakhir yang terkait pengawetan bambu dan kayu. Hasil dari telaah literatur dan observasi lapangan kemudian dianalisis dan digunakan untuk memperoleh gambaran metode dan bahan pengawet yang diguankan dalam pengawetan bambu-kayu di Indonesia.

\section{HASIL DAN PEMBAHASAN}

\subsection{Studi Literatur}

Dari hasil telaah literatur, ditemukan delapan belas publikasi terkait topik pengawetan bambu (tabel 1) dari beberapa jurnal yang sudah melalui tahapan penyaringan. Pada tabel 1 akan teridentifikasi topik bahasan sesuai dengan kronologis waktu publikasi, yakni dalam rentang tahun 2004 hingga 2018. 
Penulis juga mengumpulkan penelitian yang berkaitan dengan pengawetan kayu (tabel 2) yang dilanjutkan dengan melakukan identifikasi terhadap publikasi ilmiah yang terkait metode atau tata cara pengawetan, material dan bahan pengawetan termasuk konsenterasi larutan yang dicampur pada pengawetan bambu-kayu yang dilakukan (tabel 3 dan 4)

Tabel 1. Penelitian terdahulu terkait pengawetan bambu

\begin{tabular}{|c|c|c|}
\hline No & Judul penelitian & Peneliti \& Tahun \\
\hline 1. & Pengawetan Bambu Talang Secara Sederhana & (Novriyanti \& Nurrohman, 2004) \\
\hline 2. & Pengujian Sifat Mekanik Bambu (Metode Pengawetan Dengan Boraks) & (Handayani, 2007) \\
\hline 3. & $\begin{array}{l}\text { Pengaruh Ekstrak Tembakau Terhadap Serangan Rayap Kayu Kering } \\
\text { Cryptotermes Cynocephalus Light, Pada Bambu Apus (Gigantochloa Apus } \\
\text { Kurz) }\end{array}$ & (Hadikusumo, 2007) \\
\hline 4. & $\begin{array}{l}\text { Pengawetan Bambu Dengan Alat Buchery-Morisco Menggunakan Pestisida } \\
\text { Nabati Campuran Ekstrak Biji Mimba Dan Filtrat Umbi Gadung Sebagai } \\
\text { Bahan Pengawet Bambu Ramah Lingkungan }\end{array}$ & (Hirmawan et al., 2010) \\
\hline 5. & $\begin{array}{l}\text { Sifat Pengawet Air Laut Pada Bambu Ampel Menggunakan Metode } \\
\text { Boucherie-Morisco }\end{array}$ & $\begin{array}{l}\text { (Ismail, Morisco, \& Prayitno, } \\
\text { 2010) }\end{array}$ \\
\hline 6. & $\begin{array}{l}\text { Pemberdaya-an Pengerajin Furniture Bambu dalam Usaha Peningkatan } \\
\text { Jumlah serta Mutu Ekspor Kerajinan Bambu di Kabupaten Gianyar Bali }\end{array}$ & $\begin{array}{l}\text { (Widnyana, Budiasa, \& Sujana, } \\
\text { 2010) }\end{array}$ \\
\hline 7. & $\begin{array}{l}\text { Pengaruh Pengawetan Bambu Wulung Dengan Asap Cair Tempurung Kelapa } \\
\text { Terhadap Mortalitas Rayap Kayu Kering }\end{array}$ & $\begin{array}{l}\text { (Siswanto, Saputra, \& Amrulloh, } \\
\text { 2011) }\end{array}$ \\
\hline 8. & $\begin{array}{l}\text { Pemilihan Parameter Pre Treatment Pada Proses Pengawetan Bambu } \\
\text { Leminasi }\end{array}$ & $\begin{array}{l}\text { (Nurkertamanda, Andreina, \& } \\
\text { Widiani, 2011) }\end{array}$ \\
\hline 9. & $\begin{array}{l}\text { Pengaruh Waktu Perendaman Bambu Dan Penggunaan Borak-Barik } \\
\text { Terhadap Tingkat Keawetan Bambu }\end{array}$ & (Susilaning \& Suheryanto, 2012) \\
\hline 10. & $\begin{array}{l}\text { Ketahanan Bambu Petung (Dendrocalamus asper Backer) Yang Diawetkan } \\
\text { Dengan CCB Terhadap Serangan Penggerek Di Laut }\end{array}$ & (Muslich \& Rulliaty, 2014) \\
\hline 11. & $\begin{array}{l}\text { Pemanfaatan Boraks Untuk Pengawetan Bambu Betung (Dendrocalamus } \\
\text { asper Backer) Terhadap Serangan Rayap Tanah (Captotermes curvignathus) }\end{array}$ & $\begin{array}{l}\text { (Hamzah, Pujirahayu, \& Tama, } \\
\text { 2016) }\end{array}$ \\
\hline 12. & $\begin{array}{l}\text { Pemanfaatan Kulit Bakau (Rhizophora mucronata) Sebagai Bahan Pengawet } \\
\text { Bambu Petung (Dendrocalamus asper) Terhadap Serangan Kumbang Bubuk } \\
\text { (Dinoderus minutus) }\end{array}$ & $\begin{array}{l}\text { (Hadjar, Pujirahayu, } \\
\text { Khaeruddin, 2016) }\end{array}$ \\
\hline 13. & $\begin{array}{l}\text { Pengaruh Perendaman Dalam Air Sungai Dan Air Laut Terhadap Daya Tahan } \\
\text { Tulangan Bambu Petung Asal Tomohon }\end{array}$ & (Pojoh, 2017) \\
\hline 14. & $\begin{array}{l}\text { Pengawetan Ramah Lingkungan Pada Usaha Bambu Tradisional } \\
\text { Berorientasi Ekspor Di Desa Belega Gianyar }\end{array}$ & $\begin{array}{l}\text { (Negara, Simpen, \& Sasmita, } \\
\text { 2017) }\end{array}$ \\
\hline 15. & $\begin{array}{l}\text { Karakteristik Limbah Pengawet Bambu Petung Dan Gewang Yang } \\
\text { Mengandung Boron Dan Copper-Chrome-Boron Serta Alternatif } \\
\text { Pengelolaannya }\end{array}$ & (Wardiha \& Dibya, 2017) \\
\hline 16. & Analisis Jalur Kritis Penerapan Teknologi Pada Konstruksi Atap Sirap Bambu & $\begin{array}{l}\text { (Damayanti, Agustiningtyas, \& } \\
\text { Kuswara, 2017) }\end{array}$ \\
\hline 17. & $\begin{array}{l}\text { Pengawetan Bambu Dengan Metode Vertikal Soak Diffusion (VSD) Di Desa } \\
\text { Bokol Kecamatan Kemangkon Kabupaten Purbalingga }\end{array}$ & $\begin{array}{l}\text { (Widyaningrum, } \\
\text { Pamudji, \& Hermanto, n.d.) }\end{array}$ \\
\hline 18. & $\begin{array}{l}\text { Pengaruh Ekstrak Daun Cengkeh (Syzygium Aromaticum) Dalam } \\
\text { Pengawetan Bambu Betung (Dendrocalam-us Asper Backer) Terhadap } \\
\text { Serangan Kumbang Bubuk }\end{array}$ & $\begin{array}{l}\text { (Hamzah, Pujirahayu, Hadjar, \& } \\
\text { Rosdia, 2018) }\end{array}$ \\
\hline
\end{tabular}

Sumber: hasil telaah literatur, 2018 
Tabel 2. Penelitian terdahulu terkait pengawetan kayu

\begin{tabular}{|c|c|c|}
\hline No & Judul penelitian & Peneliti / tahun \\
\hline 1. & Sifat Penyerapan Bahan Pengawet Pada Beberapa Jenis Kayu Bangunan & (Kusumaningsih, 2008) \\
\hline 2. & $\begin{array}{l}\text { Aplikasi Asap Cair Dari Kayu Laban (Vitex pubescens Vahl) Untuk } \\
\text { Pengawetan Kayu Karet }\end{array}$ & $\begin{array}{l}\text { (Prawira, Oramahi, Setyawati, \& } \\
\text { Diba, 2009) }\end{array}$ \\
\hline 3. & $\begin{array}{l}\text { Pengawetan Kayu Karet (Hevea brasiliensis) Menggunakan Trusi Dengan } \\
\text { Metode Vakum Tekan }\end{array}$ & (Mahdi, 2009) \\
\hline 4. & $\begin{array}{l}\text { Pemanfaatan Ekstrak Kulit Kayu Gerunggang (Cratoxylon arborescens BI) } \\
\text { Untuk Pengawetan Kayu Karet (Hevea brasiliensis) Dari Serangan Rayap } \\
\text { Tanah (Coptotermes curvignathus Holmgren) }\end{array}$ & $\begin{array}{l}\text { (Daviyana, Wardenaar, \& Yanti, } \\
\text { 2010) }\end{array}$ \\
\hline 5. & $\begin{array}{l}\text { Pemanfaatan Asap Cair Dari Tempurung Kelapa Sebagai Bahan Pengawet } \\
\text { Kayu Karet (Hevea Brasiliensis Muell.Arg) }\end{array}$ & $\begin{array}{l}\text { (Sumedi, Budiarso, \& Kusuma, } \\
\text { 2011) }\end{array}$ \\
\hline 6. & $\begin{array}{l}\text { Efektivitas Pengawetan Kayu Terhadap Serangan Rayap Dengan } \\
\text { Menggunakan Bahan Pengawet Ekstrak Tembakau dan Urea }\end{array}$ & (Prasetyo \& Darmono, 2012) \\
\hline 7. & $\begin{array}{l}\text { Pengaruh Lama Perendaman Kayu Albasia (Albizia falcataria L) Dalam } \\
\text { Minyak Pirolisis Sampah Plastik Terhadap Serangan Rayap Tanah } \\
\text { (Microtermes inspiratus Kemner) }\end{array}$ & $\begin{array}{l}\text { (Dewi, Pratiknyo, \& Suparjana, } \\
\text { 2013) }\end{array}$ \\
\hline 8. & $\begin{array}{l}\text { Pemanfaatan Campuran Boraks Dan Asam Borat Sebagai Bahan } \\
\text { Pengawetan Kayu Terhadap Serangan Rayap }\end{array}$ & $\begin{array}{l}\text { (Darmono, Atun, \& Prasetyo, } \\
\text { 2013) }\end{array}$ \\
\hline 9. & $\begin{array}{l}\text { Pengawetan Kayu Tisuk (Hibiscus macrophyllus Roxb) Melalui Rendaman } \\
\text { Dingin Dengan Bahan Pengawet Boric Acid Equivalent }\end{array}$ & (Suhaendah \& Siarudin, 2014) \\
\hline 10. & $\begin{array}{l}\text { Pengaruh Pengawetan Rendaman Dingin Asam Borak Terhadap Kualitas } \\
\text { Papan Dan Bingkai Reng Kayu Aren Sebagai Bahan Bangunan }\end{array}$ & (Petandung, 2014) \\
\hline 11. & $\begin{array}{l}\text { Sifat Keawetan Alami Dan Pengawetan Kayu Mangium, Manii Dan Sengon } \\
\text { Secara Rendaman Dingin Dan Rendaman Panas Dingin }\end{array}$ & (Priadi \& Pratiwi, 2014) \\
\hline 12. & $\begin{array}{l}\text { Pemanfaatan Tannin Kulit Kayu Akasia Untuk Pengawetan Jati Putih } \\
\text { (Gmelina arborea) Terhadap Rayap Tanah (Coptotermes curvignathus } \\
\text { holmgren) }\end{array}$ & $\begin{array}{l}\text { (Pujirahayu, Uslinawaty, } \\
\text { Hadjar, 2015) }\end{array}$ \\
\hline 13. & $\begin{array}{l}\text { Pengaruh Bahan Pengawet Akonafos Dan Buah Bintaro Terhadap Ketahanan } \\
\text { Kayu Akasia (Acacia mangium) Dengan Sistem Kubur }\end{array}$ & (Lewar, 2015) \\
\hline 14. & $\begin{array}{l}\text { Pemanfaatan Asap Cair Dari Tempurung Kelapa Sebagai Bahan Pengawet } \\
\text { Kayu Karet }\end{array}$ & (Nola, 2016) \\
\hline 15. & $\begin{array}{l}\text { Pengawetan Kayu Sengon Melalui Rendaman Dingin Menggunakan Bahan } \\
\text { Pengawet Enbor SP Ditinjau Terhadap Sifat Mekanik }\end{array}$ & $\begin{array}{l}\text { (Pangestuti, Lashari, } \\
\text { Hardomo, 2016) }\end{array}$ \\
\hline 16. & $\begin{array}{l}\text { Pengaruh Lama Penyimpanan Cuka Kayu Galam Pada Pengawetan Kayu } \\
\text { Karet (Hevea brasiliensis Muell. Arg) Terhadap Serangan Rayap }\end{array}$ & $\begin{array}{l}\text { (Ulfah, Lusyiani, \& Harionarso, } \\
\text { 2016) }\end{array}$ \\
\hline 17. & $\begin{array}{l}\text { Teknologi Asap Cair Dari Tempurung Kelapa, Tongkol Jagung, Dan Bambu } \\
\text { Sebagai Penyempurna Struktur Kayu }\end{array}$ & (Anggraini, 2017) \\
\hline 18. & $\begin{array}{l}\text { Pewarnaan Kayu Sengon (Paraserainthes falcataria Linn) Dari Ekstrak } \\
\text { Limbah Kulit Kayu Bakau (Rhizophora apiculata Blume) : Uji Ketahanan } \\
\text { Warna Dan Keawetan Kayu }\end{array}$ & $\begin{array}{l}\text { (Wardyani, Diba, \& Nurhaida, } \\
\text { 2017) }\end{array}$ \\
\hline 19. & $\begin{array}{l}\text { Efektivitas Bioatraktan Dari Bahan Alami Terhadap Rayap Tanah } \\
\text { (Coptotermes curvignathus Holmgren) }\end{array}$ & (Permana \& Husni, 2017) \\
\hline 20. & $\begin{array}{l}\text { Pengaruh Lama Pengasapan Terhadap Sifat Fisik Dan Mekanik Kayu Laban } \\
\text { (Vitex pubescens) Dan Akasia (Acacia mangium Wild) }\end{array}$ & (Penus, Diba, \& Sisillia, 2017) \\
\hline 21. & $\begin{array}{l}\text { Pengaruh Konsenterasi Asam Sulfat Dan Lama Perendaman Terhadap Kuat } \\
\text { Lentur Kayu Kelapa Implementasi Pada Mata Kuliah IImu Bahan Bangunan }\end{array}$ & $\begin{array}{l}\text { (Listyorini, Murtiono, \& Agustin, } \\
\text { 2018.) }\end{array}$ \\
\hline
\end{tabular}

Sumber: Analisis Penulis, 2018 
Tabel 3. Metode dan bahan pengawetan bambu berdasarkan pada penelitian terdahulu

\begin{tabular}{|c|c|c|c|}
\hline No & Peneliti & Metode / Material & $\begin{array}{c}\text { Bahan Pengawet / Konsentrasi } \\
(\%)\end{array}$ \\
\hline 1. & $\begin{array}{l}\text { (Novriyanti \& } \\
\text { Nurrohman, 2004) }\end{array}$ & $\begin{array}{l}\text { Rendaman Dingin/ Bambu Talang Ngarai } \\
\text { Sianok Sumatera Barat }\end{array}$ & Senyawa Boron / 15\% \\
\hline 2. & (Handayani, 2007) & $\begin{array}{l}\text { Bambu didirikan terbalik / Bambu Ori dan } \\
\text { Wulung Wilayah Yogyakarta }\end{array}$ & Boraks (Na2B4O7) / 10\% \\
\hline 3. & $\begin{array}{l}\text { (Hadikusumo, } \\
2007 \text { ) }\end{array}$ & $\begin{array}{l}\text { Difusi (Bambu direndam } 5 \text { hari) / Bambu Apus } \\
\text { Dusun Krapyak Wedomartani; Yogyakarta }\end{array}$ & $\begin{array}{c}\text { 4,32 kg tembakau dalam } 18 \text { liter } \\
\text { air; berasal di Ngemplak, Sleman } \\
\text { Yogyakarta }\end{array}$ \\
\hline 4. & $\begin{array}{l}\text { (Hirmawan et al., } \\
\text { 2010) }\end{array}$ & $\begin{array}{l}\text { Buchery-Morisco/ } \\
\text { Bambu tidak disebutkan jenisnya }\end{array}$ & $\begin{array}{l}\text { Pestisida nabati campuran } \\
\text { ekstrak biji mimba dan filtrat umbi } \\
\text { gadung / Tidak dijelaskan hanya } \\
1 \mathrm{~kg} \text { mimba dan } 1 \mathrm{~kg} \text { Gadung }\end{array}$ \\
\hline 5. & $\begin{array}{l}\text { (Ismail et al., } \\
\text { 2010) }\end{array}$ & $\begin{array}{l}\text { Boucherie-Morisco / Bambu Ampel } \\
\text { Yogyakarta }\end{array}$ & $\begin{array}{c}\text { Air laut salinitas } 17,6 \% \text { ditambah } \\
\text { garam }(\mathrm{NaCl} 10 \%\end{array}$ \\
\hline 6. & $\begin{array}{l}\text { (Widnyana et al., } \\
\text { 2010) }\end{array}$ & $\begin{array}{l}\text { VSD (Vertikal Soak Diffusion) 10-14 hari / } \\
\text { Bambu tidak disebutkan jenisnya }\end{array}$ & Borak Boric / Tidak dijelaskan \\
\hline 7. & $\begin{array}{l}\text { (Siswanto et al., } \\
\text { 2011) }\end{array}$ & $\begin{array}{l}\text { Boucherie-Morisco / Bambu Wulung Gamping } \\
\text { Yogyakarta usia >3 tahun }\end{array}$ & $\begin{array}{c}\text { Asap cair tempurung kelapa } \\
\text { grade } 2 \text { dan } 3 / 5 \%\end{array}$ \\
\hline 8. & $\begin{array}{l}\text { (Nurkertamanda } \\
\text { et al., 2011) }\end{array}$ & $\begin{array}{l}\text { Rendaman Dingin / Bambu Bilah Apus kadar } \\
\text { air } 12 \%\end{array}$ & Ekstrak daun Mimba / 20\% \\
\hline 9. & $\begin{array}{l}\text { (Susilaning \& } \\
\text { Suheryanto, 2012) }\end{array}$ & $\begin{array}{l}\text { Rendaman Dingin/ Bambu Petung dan Ampel } \\
\text { Segar Yogyakarta }\end{array}$ & $\begin{array}{c}\text { Alami, perendaman pada air } \\
\text { mengalir } 3 \text { bulan dan kimia, Borak } \\
\text { Boric } 10 \%\end{array}$ \\
\hline 10. & $\begin{array}{l}\text { (Muslich \& } \\
\text { Rulliaty, 2014) }\end{array}$ & $\begin{array}{l}\text { Modifikasi Boucherie } 7 \text { hari / Bambu Petung } \\
\text { 12m Rangkas Bitung Jawa Barat }\end{array}$ & $\begin{array}{c}\text { Copper-bichromated boron (CCB) } \\
\qquad / 3 \%\end{array}$ \\
\hline 11. & $\begin{array}{l}\text { (Hamzah et al., } \\
\text { 2016) }\end{array}$ & $\begin{array}{l}\text { Rendaman Dingin selama } 3 \text { bulan/ Bambu } \\
\text { Betung Kendari }\end{array}$ & Boraks / 1\% \\
\hline 12. & (Pojoh, 2017) & $\begin{array}{l}\text { Rendaman Dingin / Bambu Betung Tomohon } \\
\text { Manado }\end{array}$ & $\begin{array}{l}\text { Perendaman dalam air sungai } \\
\quad \text { dan air laut } 4 \text { bulan }\end{array}$ \\
\hline 13. & $\begin{array}{l}\text { (Negara et al., } \\
2017 \text { ) }\end{array}$ & $\begin{array}{l}\text { Gravitasi / Bambu tidak dijelaskan jenisnya, } \\
\text { Lokasi Bali }\end{array}$ & $\begin{array}{l}\text { Bahan biodegradable khitosan } \\
\text { isolasi kulit udang limbah restoran } \\
\text { / tidak dijelaskan }\end{array}$ \\
\hline 14. & $\begin{array}{l}\text { (Wardiha \& Dibya, } \\
\text { 2017) }\end{array}$ & $\begin{array}{l}\text { Rendaman Dingin / Bambu Petung dan } \\
\text { Gewang, Lokasi Bali }\end{array}$ & Boron dan CCB / tidak disebutkan \\
\hline 15. & $\begin{array}{l}\text { (Damayanti et al., } \\
\text { 2017) }\end{array}$ & Boucherie/ Sirap Bambu, Lokasi Bali & Boron / 5\% \\
\hline 16. & $\begin{array}{l}\text { (Widyaningrum et } \\
\text { al., n.d.) }\end{array}$ & $\begin{array}{l}\text { VSD (Vertikal Soak Diffusion) / Bambu tidak } \\
\text { dijelaskan; Lokasi Purbalingga }\end{array}$ & $\begin{array}{l}\text { Larutan Borate (campuran borax } \\
\text { dan boric acid) / Tidak dijelaskan }\end{array}$ \\
\hline 17. & $\begin{array}{l}\text { (Hadjar et al., } \\
\text { 2016) }\end{array}$ & $\begin{array}{l}\text { Peredaman Panas / Bambu Betung } \\
\text { Lokasi Kendari }\end{array}$ & Ekstrak kulit bakau / $15 \%$ \\
\hline 18. & $\begin{array}{l}\text { (Hamzah et al., } \\
\text { 2018) }\end{array}$ & $\begin{array}{l}\text { Rendaman Dingin / Bambu Betung Lokasi } \\
\text { Sulawesi Tenggara }\end{array}$ & Ekstrak daun cengkeh / 1,5\% \\
\hline
\end{tabular}

Sumber: hasil telaah literatur, 2018 
Tabel 4. Metode dan bahan pengawetan kayu berdasarkan pada penelitian terdahulu

\begin{tabular}{|c|c|c|c|}
\hline No & Peneliti & Metode / Material & Bahan Pengawet / Kons \\
\hline 1. & $\begin{array}{l}\text { (Kusumaningsih, } \\
\text { 2008) }\end{array}$ & $\begin{array}{l}\text { Rendaman Dingin / Kayu Sengon, } \\
\text { Meranti Merah, Kelapa, Surian , } \\
\text { Lokasi Yogyakarta }\end{array}$ & $\begin{array}{l}\text { Boraks }\left(\mathrm{Na}_{2} \mathrm{~B}_{4} \mathrm{O}_{7} .5 \mathrm{H}_{2} \mathrm{O}\right) \text {, Terusi }\left(\mathrm{CuSO}_{4}\right) \\
\text { masing-masing } 5 \% \text { dan selama } 5 \text { hari }\end{array}$ \\
\hline 2. & $\begin{array}{l}\text { (Prawira et al., } \\
\text { 2009) }\end{array}$ & $\begin{array}{l}\text { Tidak dijelaskan / Kayu Karet, } \\
\text { Lokasi Pontianak }\end{array}$ & $\begin{array}{l}\text { Asap cair kayu laban / } 10 \% \text { dan } 15 \% \text { suhu } \\
\text { pirolisis } 400 \text { derajat Celcius }\end{array}$ \\
\hline 3. & (Mahdi, 2009) & $\begin{array}{l}\text { Vakum Tekan } 2 \text { bulan / Kayu Karet, } \\
\text { Lokasi Samarinda }\end{array}$ & Trusi / 1\% dan $2 \%$ \\
\hline 4. & $\begin{array}{l}\text { (Daviyana et al., } \\
\text { 2010) }\end{array}$ & $\begin{array}{l}\text { Tidak dijelaskan / Kayu Karet, } \\
\text { Lokasi Pontianak }\end{array}$ & $\begin{array}{l}\text { Ekstrak kulit kayu gerunggang / Tidak } \\
\text { dijelaskan }\end{array}$ \\
\hline 5. & $\begin{array}{l}\text { (Sumedi et al., } \\
\text { 2011) }\end{array}$ & $\begin{array}{l}\text { Rendaman Dingin / Kayu Karet, } \\
\text { Lokasi Samarinda }\end{array}$ & Asap cair tempurung kelapa / $20 \%$ \\
\hline 6. & $\begin{array}{l}\& \\
2012)\end{array}$ & $\begin{array}{l}\text { Rendaman Dingin / Kayu Sengon } \\
\text { Lokasi Yogyakarta }\end{array}$ & Ekstrak tembakau $100 \%$ dan Urea $15 \%$ \\
\hline 7. & $\begin{array}{l}\text { (Dewi et al., } \\
\text { 2013) }\end{array}$ & $\begin{array}{l}\text { Rendaman Dingin / Kayu Albasia } \\
\text { Lokasi Purwokerto }\end{array}$ & $\begin{array}{l}\text { Minyak pirolisis sampah plastik suhu } 600 \mathrm{C} / \\
\text { Tidak dijelaskan }\end{array}$ \\
\hline 8. & $\begin{array}{l}\text { (Dar } \\
2013\end{array}$ & $\begin{array}{l}\text { Rendaman Dingin / Kayu Sengon } \\
\text { Lokasi Klaten Jawa Tengah }\end{array}$ & $\begin{array}{l}\text { Campuran Borak } \\
\text { Boraks dengan } 1\end{array}$ \\
\hline 9. & $\begin{array}{l}\text { (Suhaendah \& } \\
\text { Siarudin, 2014) }\end{array}$ & $\begin{array}{l}\text { Rendaman Dingin / Kayu Tisuk } \\
\text { Desa Sukamulih Sariwangi } \\
\text { Tasikmalaya Jawa Barat }\end{array}$ & $\begin{array}{l}\text { Boric Acid Equivalent (BAE) / } 5 \% \text { dan } 10 \% \\
\text { lama perendaman } 3 \text { dan } 7 \text { hari }\end{array}$ \\
\hline 10. & $\begin{array}{l}\text { (Petand } \\
2014)\end{array}$ & $\begin{array}{l}\text { Rendaman Dingin / Papan, bingkai } \\
\text { reng dari Pohon Aren, Lokasi } \\
\text { Manado }\end{array}$ & Asa \\
\hline 11. & $\begin{array}{l}\text { (Priadi \& Pratiwi, } \\
\text { 2014) }\end{array}$ & $\begin{array}{l}\text { Rendaman Panas-Dingin / Kayu } \\
\text { Mangium, Manii, Sengon, Lokasi } \\
\text { Bogor }\end{array}$ & $\begin{array}{l}\text { Diffusol CB berbahan aktif tembaga, krom dan } \\
\text { boron / } 5 \%\end{array}$ \\
\hline 12. & $\begin{array}{l}\text { (Puji } \\
\text { al., } 2\end{array}$ & $\begin{array}{l}\text { Rendaman Dingin } 24-48 \text { jam / Kayu } \\
\text { Jati Putih (Gmelina arborea) usia } \\
10 \text { tahun }\end{array}$ & Ekstrak t \\
\hline 13. & (Lewar, 2015) & $\begin{array}{l}\text { Sistem kubur } 3 \text { bulan / Kayu } \\
\text { Akasia, Lokasi Samarinda }\end{array}$ & Akonafos dan bu \\
\hline 14. & (Nola, 2 & $\begin{array}{l}\text { Rendaman Dingin / Kayu Karet, } \\
\text { Lokasi Samarinda }\end{array}$ & Asap cair tempurung kelapa / $40 \%$ \\
\hline 15. & $\begin{array}{l}\text { (Pan } \\
\text { al., } 2\end{array}$ & $\begin{array}{l}\text { Rendaman Dingin } 5 \text { hari / Kayu } \\
\text { Sengon, Lokasi Semarang }\end{array}$ & Enbor SP \\
\hline 16. & $\begin{array}{l}\text { (Ulfah et al., } \\
\text { 2016) }\end{array}$ & $\begin{array}{l}\text { Rendaman Dingin / Kayu karet } \\
\text { Lokasi Kalimantan Selatan }\end{array}$ & Cuka kayı \\
\hline 17. & $\begin{array}{l}\text { (Anggraini, } \\
\text { 2017) }\end{array}$ & $\begin{array}{l}\text { Rendaman Dingin / Kayu Lokasi } \\
\text { Malang }\end{array}$ & $\begin{array}{l}\text { Asap cair te } \\
\text { dan bambu / }\end{array}$ \\
\hline 18. & $\begin{array}{l}\text { (Wardyani et al., } \\
\text { 2017) }\end{array}$ & $\begin{array}{l}\text { Rendaman Panas-Dingin } 72 \text { jam / } \\
\text { Kayu Sengon Lokasi Pontianak }\end{array}$ & Ekstrak limbah kulitk kayu bakau / 5\% \\
\hline 19. & $\begin{array}{l}\text { (Permana \& } \\
\text { Husni, 2017) }\end{array}$ & $\begin{array}{l}\text { Rendaman Dingin / Kayu Pinus, } \\
\text { Lokasi Makasar }\end{array}$ & Ekstrak daun kayu putih $0,01 \%$ \\
\hline 20. & $\begin{array}{l}\text { (Penus et al., } \\
\text { 2017) }\end{array}$ & $\begin{array}{l}\text { Pengasapan } 36 \text { jam / Kayu Laban } \\
\text { dan Kayu Akasia, Lokasi Pontianak }\end{array}$ & $\begin{array}{l}\text { Pembakaran tempurung kelapa / Digunakan } \\
\text { untuk menghasilkan asap (Tidak dijelaskan) }\end{array}$ \\
\hline 21. & $\begin{array}{l}\text { (Listyorini et al., } \\
\text { n.d.) }\end{array}$ & $\begin{array}{l}\text { Rendaman Dingin / Kayu Kelapa, } \\
\text { Lokasi Solo }\end{array}$ & Konsenterasi Asam Sulfat / 1,2\% \\
\hline
\end{tabular}

Sumber: hasil telaah literatur, 2018 


\subsection{Best practice pengawetan bambu}

Observasi lapangan dilakukan oleh penelit untuk melakukan pengamatan terhadap best practice pengawetan bambu di daerah Purwomartani, Klasan, Sleman Yogyakarta. Terdapat dua macam metode proses pengawetan bambu untuk memproduksi bambu yang diawetkan. Metode pertama dengan proses perebusan bambu dengan suhu 80 derajat Celcius selama 3 jam. Metode kedua dengan cara Vertical Soak Diffusion (gambar 1) dengan bahan pengawet Boraks Boric.

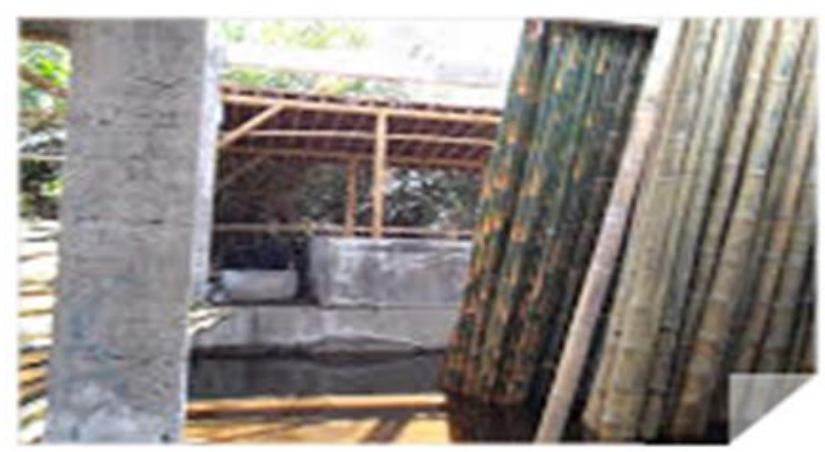

Gambar 1. Pengawetan bambu metode Vertical Soak Diffusion. (Sumber: dokumentasi peneliti, 2018)

Campuran bahan pengawet Boraks Boric digunakan pada kedua metode tersebut yaitu, konsenterasi minimal $6 \%$ dan maksimal $10 \%$. Jenis bambu yang diawetkan mulai dari bambu Petung,
Apus, Wulung, Ori, dan Pelupuh tergantung dari pemesanan. Jenis bambu yang selalu tersedia adalah jenis bambu Petung yang biasanya digunakan untuk konstruksi bangunan. Jenis ini diproduksi karena banyak yang memesan dan menggunakan untuk keperluan pembangunan, kerajinan dan sebagainya.

Terkait dengan perbandingan keefektifan dan keamanan antara zat pengawet kimia dengan dengan pengawet alami, narasumber penelitian menyatakan bahwa penggunaan bahan pengawet boraks boric, selama ini cukup efektif untuk dapat memenuhi usia layan 10 s.d 15 tahun kedepan dan dapat memproduksi bambu awet lebih banyak atau optimal. Lebih lanjut dipaparkan bahwa tingkat kepercayaan masyarakat terhadap bahan borac boric terhadap pengawetan bambu cukup tinggi. Ketika ada wacana untuk menggantinya dengan bahan pengawet dari bahan alami masyarakat masih enggan untuk mengadopsinya karena belum ada pembuktian yang signifikan terhadap usia layan dan kehandalan terhadap serangga, jamur atau bubuk rayap. Hal ini menjadi pertimbangan pengusaha bambu terkait biaya dan bisnis untuk pengawetan bambu. Dari hasil telaah literatur dan observasi lapangan, dapat diperoleh informasi berbagai macam metode pengawetan bambu-kayu serta bahan pengawetan yang telah banyak diteliti dan digunakan saat ini, baik menggunakan bahan alami maupun kimia (tabel 5).

Tabel 5. Rangkuman berbagai variasi metode dan bahan pengawet untuk pengawetan bambu-kayu

\begin{tabular}{|c|c|c|}
\hline Metode & Bahan pengawet alami & Bahan pengawet kimia \\
\hline $\begin{array}{l}\text { - Rendaman Dingin, } \\
\text { - Rendaman Panas, } \\
\text { - Rendaman Panas- } \\
\text { Dingin, } \\
\text { - Bambu didirikan } \\
\text { terbalik (gravitasi), } \\
\text { - Difusi, } \\
\text { - Bucherie, } \\
\text { - Modifikasi Bucherie- } \\
\text { Morisco, } \\
\text { - VSD (Vertical Soak } \\
\text { Difusion), } \\
\text { - Vakum Tekan, dan } \\
\text { - Pengasapan. } \\
\text { - Perendaman pada air } \\
\text { mengalir } 3 \text { bulan, } \\
\text { - Perendaman dalam } \\
\text { air sungai dan air laut } \\
4 \text { bulan. }\end{array}$ & 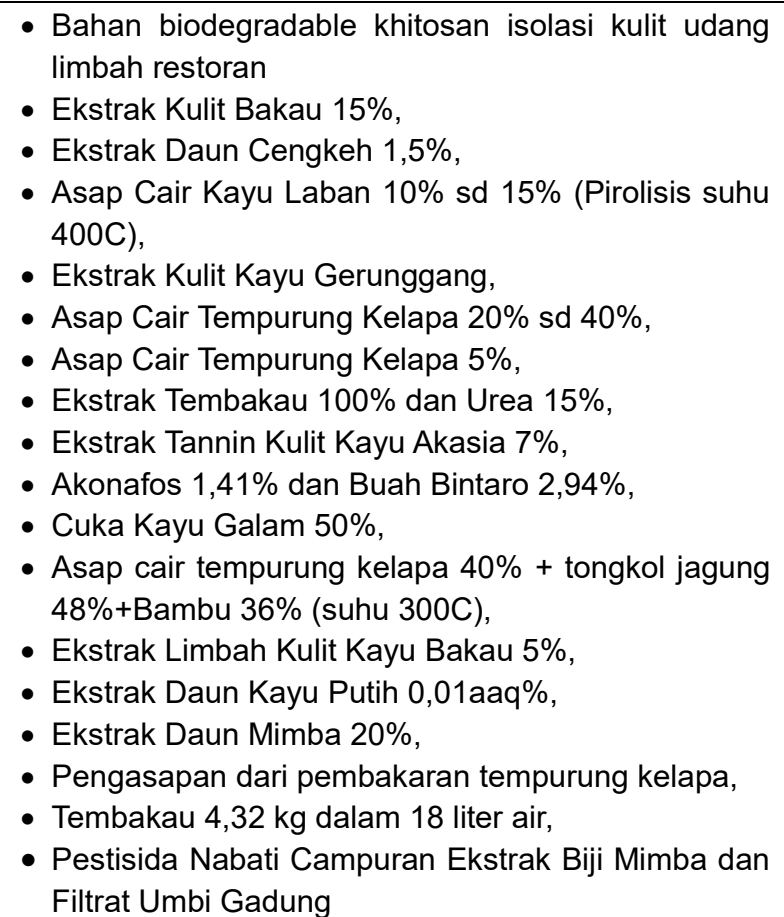 & $\begin{array}{l}\text { - Senyawa Boron } 5 \% \text { sd } 15 \% \text {, } \\
\text { - CCB (Copper-bichromated boron) } \\
3 \% \text {, } \\
\text { - Borak Boric } 1 \% \text { sd } 10 \% \text {, } \\
\text { - Boraks }\left(\mathrm{Na}_{2} \mathrm{~B}_{4} \mathrm{O}_{7} .5 \mathrm{H}_{2} \mathrm{O}\right) \text { dan } \\
\text { Terusi }\left(\mathrm{CuSO}_{4}\right), 5 \% \text {, } \\
\text { - } \text { Minyak pirolisis sampah plastik } \\
\text { suhu } 600 \mathrm{C} \text { (konsenterasi tidak } \\
\text { dijelaskan), } \\
\text { - } \text { Boric Acid Equivalent (BAE) } 5 \% \\
\text { s.d } 10 \%, \\
\text { - Diffusol CB berbahan aktif } \\
\text { tembaga, krom dan boron } 5 \%, \\
\text { - Enbor SP } 9 \%, \\
\text { - Konsenterasi Asam Sulfat } 1,2 \%, \\
\text { - } \text { Air laut salinitas } 17,6 \% \text { ditambah } \\
\text { garam (NaCl) } 10 \%,\end{array}$ \\
\hline
\end{tabular}

Sumber: hasil analisis, 2018 


\section{KESIMPULAN}

Metode pengawetan yang dilakukan dapat diterapkan untuk pengawetan bambu dan kayu tergantung dari tujuan dan kebutuhan bambu atau kayu yang diperlukan. Jika diperlukan untuk produksi banyak dengan pertimbangan waktu pengerjaan dan biaya produksi optimal, dapat menggunakan metode perendaman panas atau perebusan (waktu dan suhu tertentu) dan metode Vertical Soak Diffusion (VSD) yang prinsipnya hampir sama denga metode gravitasi. Sedangkan jika kebutuhan akan bambu lebih sedikit atau untuk kepentingan edukasi teknik lain selain kedua metode tersebut dapat digunakan, dengan pertimbanga waktu dan biaya operasional pengawetan. Bahan pengawetan yang dapat digunakan dapat menggunakan bahan alami maupun bahan kimia. Namun, dari paparan disimpulkan bahwa bahan pengawet dari zat kimia Boraks Boric lebih efektif dan umum diterapkan untuk kepentingan produksi dengan skala besar.

Terkait metode perlu diteliti terkait pengaruh pengawetan dengan cara perendaman panas atau perebusan dengan waktu dan suhu tertentu terhadap kekuatan bambu dan kayu. Sedangkan untuk bahan pengawet, perlu dilakukannya penelitian lebih lanjut terhadap bahan pengawet yang berasal dari minyak pirolisis sampah plastik (suhu 600C) untuk dipastikan berapa konsentrasi yang signifikan dalam penerapan produksi massal serta kemampuan penetrasi yang dapat diterima oleh bambu atau kayu sehingga dapat memenuhi usia layan yang dinginkan. Penelitian lebih lanjut juga dapat dilakukan untuk menguji konsentrasi, penetrasi dan ongkos produksi pengawetan bambukayu jika menggunakan bahan pengawet alami dari asap cair tempurung kelapa, tembakau dan bahan alami lainnya, agar dapat secara layak digunakan dan diterima oleh masyarakat.

\section{DAFTAR PUSTAKA}

Anggraini, S. P. A. (2017). Teknologi Asap Cair Dari Tempurung Kelapa, Tongkol Jagung, dan Bambu Sebagai Penyempurna Struktur Kayu. Seminar Nasional Inovasi Dan Aplikasi Teknologi Di Industri, D18-6.

Barly, \& Sumarni, G. (1997). Cara Sederhana Pengawetan Bambu Segar. BULETIN PENELITIAN HASIL HUTAN, 15(2), 79-86.

Charomaini Z, I. M. (2014). Budidaya Bambu Jenis Komersial. IPB Press.

Damayanti, D. P., Agustiningtyas, R. S., \& Kuswara. (2017). Analisis Jalur Kritis Penerapan Teknologi Pada Konstruksi Atap Sirap Bambu. JURNAL PEMUKIMAN, 12(2), 94-107.

Darmono, Atun, S., \& Prasetyo, S. (2013). Pemanfaatan Campuran Boraks Dan Asam Borat Sebagai Bahan Pengawetan Kayu Terhadap
Serangan Rayap. INOTEK, 17(1), 82-99.

Daviyana, S. A., Wardenaar, E., \& Yanti, H. (2010). Pemanfaatan Ekstrak Kulit Kayu Gerunggang (Cratoxylon arborescens BI) Untuk Pengawetan Kayu Karet (Hevea brasiliensis) dari Serangan Rayap Tanah (Coptotermes curvignathus Holmgren), 199-207.

Dewi, S. Y., Pratiknyo, H., \& Suparjana, T. B. (2013). Pengaruh Lama Perendaman Kayu Albasia Dalam Minyak Pirolisis Sampah Plastik Terhadap Serangan Rayap Tanah, 1-15.

Djarwanto, \& R.Sudradjat. (2002). Pengawetan Kayu Mangium Secara Rendaman Panas-Dingin Dengan Bahan Pengawet Boron Dan CCB. BULETIN PENELITIAN HASIL HUTAN, 20(1), 12-19.

Hadikusumo, S. A. (2007). Pengaruh Ekstrak Tembakau Terhadap Serangan Rayap Kayu Kering Pada Bambu Apus. JURNAL ILMU KEHUTANAN, I(2), 47-54.

Hadjar, N., Pujirahayu, N., \& Khaeruddin, M. (2016). Pemanfaatan Kulit Bakau (Rhizophora mucronata) Sebagai Bahan Pengawet Bambu Petung (Dendrocalamus asper) Terhadap Serangan Kumbang Bubuk (Dinoderus minutus). ECOGREEN, 2(2), 89-96.

Hamzah, N., Pujirahayu, N., Hadjar, N., \& Rosdia, W. ode. (2018). Pengaruh Ekstrak Daun Cengkeh (Syzygium Aromaticum) dalam Pengawetan Bambu Betung (Dendrocalamus Asper Backer) Terhadap Serangan Kumbang Bubuk. ECOGREEN, 4(1), 39-42.

Hamzah, N., Pujirahayu, N., \& Tama, S. R. (2016). Pemanfaatan Boraks Untuk Pengawetan Bambu Betung Terhadap Serangan Rayap Tanah. Ecogreen, 2.

Handayani, S. (2007). Pengujian Sifat Mekanik Bambu (Metode Pengawetan dengan Boraks), 12.

Hirmawan, B. D., Kurniawati, E., \& Indriyani, M. (2010). Pengawetan Bambu Dengan Alat BucheryMorisco Menggunakan Pestisida Nabati Campuran Ekstrak Biji Mimba Dan Filtrat Umbi Gadung Sebagai Bahan Pengawet Bambu Ramah Lingkungan (LAPORAN) (hlm. 24). MALANG: UNIVERSITAS NEGERI MALANG.

Ismail, I., Morisco, \& Prayitno, T. . (2010). Sifat Pengawet Air Laut Pada Bambu Ampel Menggunakan Metode Boucherie-Morisco.

Kusumaningsih, K. R. (2008). Sifat Penyerapan Bahan Pengawet pada Beberapa Jenis Kayu Bangunan, 10.

Lewar, D. O. (2015). Pengaruh Bahan Pengawet Akonafos Dan Buah Bintaro Terhadap Ketahanan Kayu Akasia (Acacia mangium) Dengan Sistem Kubur (Tugas Akhir). Samarinda: Program Studi 
Pengolahan Hasil Hutan Politeknik Pertanian Negeri Samarinda.

Listyorini, R., Murtiono, E. S., \& Agustin, R. S. (2018). Pengaruh Konsenterasi Asam Sulfat Dan Lama Perendaman Terhadap Kuat Lentur Kayu Kelapa Implementasi Pada Mata Kuliah IImu Bahan Bangunan. IJCEE, 4(1), 79-89.

Mahdi, A. (2009). Pengawetan Kayu Karet (Hevea brasiliensis) Menggunakan Trusi Dengan Metode Vakum Tekan (Tugas Akhir). Samarinda: Program Studi Pengolahan Hasil Hutan Politeknik Pertanian Negeri Samarinda.

Muslich, M., \& Rulliaty, S. (2014). Ketahanan Bambu Petung Yang Diawetkan Dengan CCB Terhadap Serangan Penggerek Di Laut. JURNAL PENELITIAN HASIL HUTAN, 32(3), 199-208.

Negara, I. S., Simpen, I., \& Sasmita, G. M. A. (2017). Pengawetan Ramah Lingkungan Pada Usaha Bambu Tradisional Berorientasi Ekspor Di Desa Belega Gianyar. BULETIN UDAYANA MENGABDI, 16(2), 64-70.

Nola, A. N. (2016). Pemanfaatan Asap Cair Dari Tempurung Kelapa Sebagai Bahan Pengawet Kayu Karet (Hevea brasiliensis Muell. Arg.) (TUGAS AKHIR) (hlm. 51). Samarinda: Program Studi Pengolahan Hasil Hutan Politeknik Pertanian Negeri Samarinda.

Novriyanti, E., \& Nurrohman, E. (2004). Pengawetan Bambu Talang Secara Sederhana. JURNAL PENELITIAN HASIL HUTAN, 22(4), 223-230.

Nurkertamanda, D., Andreina, W., \& Widiani, M. (2011). Pemilihan Parameter Pre Treatment Pada Proses Pengawetan Bambu Leminasi. J@TI Undip, VI(3), 155-160.

Pangestuti, E. K., Lashari, \& Hardomo, A. (2016). Pengawetan Kayu Sengon Melalui Rendaman Dingin Menggunakan Bahan Pengawet Enbor SP Ditinjau Terhadap Sifat Mekanik. JURNAL TEKNIK SIPIL \& PERENCANAAN, 18(1), 55-64.

Penus, Diba, F., \& Sisillia, L. (2017). Pengaruh Lama Pengasapan Terhadap Sifat Fisik Dan Mekanik Kayu Laban (Vitex pubescens) Dan Akasia (Acacia mangium Wild). JURNAL HUTAN LESTARI, 5(3), 732-740.

Permana, R. D., \& Husni, H. (2017). Efektivitas Bioatraktan Dari Bahan Alami Terhadap Rayap Tanah (Coptotermes curvignathus Holmgren). JURNAL HUTAN LESTARI, 5(3), 629-688.

Petandung, P. (2014). Pengaruh Pengawetan Rendaman Dingin Asam Borak Terhadap Kualitas Papan Dan Bingkai Reng Kayu Aren Sebagai Bahan Bangunan. JURNAL PENELITIAN TEKNOLOGI INDUSTRI, 6(1), 31-42.

Pojoh, B. (2017). Pengaruh Perendaman Dalam Air Sungai Dan Air Laut Terhadap Daya Tahan
Tulangan Bambu Petung Asal Tomohon. JURNAL PENELITIAN TEKNOLOGI INDUSTRI, 9(1), 3748.

Prasetyo, S., \& Darmono. (2012). Efektivitas Pengawetan Kayu Terhadap Serangan Rayap Dengan Menggunakan Bahan Pengawet Ekstrak Tembakau Dan Urea. JURNAL TEKNIK SIPIL, 115.

Prawira, H., Oramahi, H. ., Setyawati, D., \& Diba, F. (2009). Aplikasi Asap Cair Dari Kayu Laban (Vitex pubescens Vahl) Untuk Pengawetan Kayu Karet, $16-22$.

Priadi, T., \& Pratiwi, G. A. (2014). Sifat Keawetan Alami Dan Pengawetan Kayu Mangium, Manii Dan Sengon Secara Rendaman Dingin Dan Rendaman Panas Dingin. JURNAL TEKNOLOGI KAYU TROPIS, 12(2), 118-126.

Pujirahayu, N., Uslinawaty, Z., \& Hadjar, N. (2015). Pemanfaatan Tannin Kulit Kayu Akasia Untuk Pengawetan Jati Putih (Gmelina arborea) Terhadap Rayap Tanah (Coptotermes curvignathus holmgren). ECOGREEN, 1(1), 2936.

Siswanto, M. F., Saputra, A., \& Amrulloh, H. (2011). Pengaruh Pengawetan Bambu Wulung Dengan Asap Cair Tempurung Kelapa Terhadap Mortalitas Rayap Kayu Kering. Dinamika TEKNIK SIPIL, 11(2), 151-154.

SNI 03-5010.1-1999. (t.t.). Pengawetan Kayu Untuk Perumahan Dan Gedung.

Suhaendah, E., \& Siarudin, M. (2014). Pengawetan Kayu Tisuk Melalui Rendaman Dingin Dengan Bahan Pengawetan Boric Acid Equivalent. JURNAL PENELITIAN HASIL HUTAN, 32(2), 103-110.

Sulistyowati, C. A. (1997). Pengawetan Bambu. WACANA, 6, 11-13.

Sumedi, A., Budiarso, E., \& Kusuma, I. W. (2011). Pemanfaatan Asap Cair Dari Tempurung Kelapa Sebagai Bahan Pengawet Kayu Karet (Hevea Brasiliensis Muell.Arg). JURNAL KEHUTANAN TROPIKA HUMIDA, 4(1), 1-11.

Suriani, E. (2017). Bambu Sebagai Alternatif Penerapan Material Ekologis: Potensi dan Tantangannya. EMARA: Indonesian Journal of Architecture, 3(1), 33-42

Susilaning, L., \& Suheryanto, D. (2012). Pengaruh Waktu Perendaman Bambu Dan Penggunaan Borak-Barik Terhadap Tingkat Keawetan Bambu. PROSIDING SEMINAR NASIONAL APLIKASI SAINS \&TEKNOLOGI (SNAST), III, A94-A101.

Ulfah, D., Lusyiani, \& Harionarso, B. (2015). Pengaruh Lama Penyimpanan Cuka Kayu Galam Pada Pengawetan Kayu Karet (Hevea brasiliensis Muell. Arg) Terhadap Serangan Rayap. JURNAL 
HUTAN TROPIS, 4(1), 21-27.

Wardiha, M. W., \& Dibya, I. K. Y. P. (2017). Karakteristik Limbah Pengawet Bambu Petung Dan Gewang Yang Mengandung Boron Dan Copper-ChromeBoron Serta Alternatif Pengelolaannya. JURNAL PEMUKIMAN, 12(2), 64-69.

Wardyani, Y., Diba, F., \& Nurhaida. (2017). Pewarnaan Kayu Sengon (Paraserainthes falcataria Linn) Dari Ekstrak Limbah Kulit Kayu Bakau (Rhizophora apiculata Blume): Uji Ketahanan Warna Dan Keawetan Kayu. JURNAL HUTAN LESTARI, 5(3), 618-628.
Widnyana, I. K., Budiasa, M., \& Sujana, P. (2010). Pemberdayaan Pengerajin Furniture Bambu dalam Usaha Peningkatan Jumlah serta Mutu Ekspor Kerajinan Bambu di Kabupaten Gianyar Bali. MAJALAH APLIKASI IPTEKS NGAYAH, 1(1), 52-62.

Widyaningrum, A., Sudibyo, G. H., Pamudji, G., \& Hermanto, N. I. S. (2017). Pengawetan Bambu Dengan Metode Vertikal Soak Diffusion (VSD) Di Desa Bokol Kecamatan Kemangkon Kabupaten Purbalingga. PROSIDING Pengembangan Sumber Daya Perdesaan dan Kearifan Lokal Berkelanjutan VII, VII. 